\title{
A first list of lichenicolous fungi from India
}

\section{Mikhail P. Zhurbenko}

Laboratory of the Systematics and Geography of Fungi, Komarov Botanical Institute, Russian Academy of Sciences, Professor Popov 2, St.-Petersburg, 197376, Russia (e-mail: zhurb58@gmail.com)

Received 8 October 2013 / Accepted 3 November 2013/ Published 9 November 2013

Zhurbenko, M.P. 2013. A first list of lichenicolous fungi from India. - Mycobiota 3: 19-34. doi: 10.12664/ mycobiota.2013.03.03

\begin{abstract}
Thirty six species of lichenicolous fungi are reported from India, all but one being new to the country. Endococcus incrassatus and Monodictys epilepraria are new to Asia. Endocarpon and Melanelixia are new host genera for Endococcus incrassatus and Lichenoconium xanthoriae respectively. Cladosporium licheniphilum is for the first time reported on Xanthoria candelaria, as is Corticifraga peltigerae on Peltigera elisabethae and P. ponojensis, and Nectriopsis lecanodes on Peltigera elisabethae and P. scabrosa. Two possibly undescribed species of lichenicolous fungi, viz. Cercidospora sp. on Lecanora sp. and Lichenostigma subgen. Lichenogramma sp. on Seirophora contortuplicata, are briefly described and discussed. Host lichens Peltigera ponojensis, P. scabrosa and Seirophora contortuplicata are new to India.
\end{abstract}

Key words: Asia, biogeography, India, lichen-inhabiting fungi, lichens, taxonomy

\section{Introduction}

Knowledge of Asian lichenicolous fungi is still very scant, most reports being from Siberia (Russia) and south-western Asia (mostly Turkey). No special survey of these fungi has been performed in India, wherefrom just seven species were formerly known: Abrothallus peyritschii (Stein) Kotte growing on Vulpicida pinastri from Himachal Pradesh (Alstrup \& Ahti 2007), Endococcus rugulosus Nyl. on Rhizocarpon disporum from Kashmir (Triebel 1989), Homostegia piggotii (Berk. \& Broome) P. Karst. on Parmelia sp. from Uttaranchal (Alstrup \& Ahti 2007), Lichenopeltella swaminathaniana Harih., Mibey \& D. Hawksw. on Porina sp. from Tamil Nadu (Hariharan et al. 1996), Opegrapha foreaui (Moreau) Hafellner \& R. Sant. on Heterodermia leucomela from Madras (Coppins \& Kondratyuk 1998), Phyllosticta galligena Moreau on Parmotrema perforatum from Shembaganur (Moreau 1951) and Skyttea fusispora Sherwood, D. Hawksw. \& Coppins on Ochrolechia trochophora from Assam (Sherwood et al. 1981). 
In April and May 2013 I gathered a small collection of lichenicolous fungi in Jammu and Kashmir State of India. Its identification yielded a list of 36 species, presented below, all but one being new to India and two new to Asia. Examined material also includes two possibly yet undescribed species of Cercidospora and Lichenostigma subgen. Lichenogramma. Some species revealed broader variation of the ascomatal characters compared with the descriptions mainly based on the European and/or on the aged herbarium collections. Pertinent notes on such observations are also provided.

\section{Materials and methods}

The study is based on 49 specimens, which were examined using Zeiss microscopes Stemi 2000-CS and Axio Imager A1 equipped with Nomarski differential interference contrast optics (DIC). Microscopical examination was done in water, $10 \% \mathrm{KOH}(\mathrm{K})$, Lugol's iodine, directly (I) or after $\mathrm{KOH}$ pre-treatment (K/I), or Brilliant Cresyl blue (BCr). Measurements were taken from water mounts, unless otherwise indicated, and refer to recently collected material (cf. vital taxonomy: Baral 1992). The length and breadth of the asci, ascospores, conidia and cells of vegetative hyphae, as well as the length/breadth ratio $(\mathrm{l} / \mathrm{b})$ of the ascospores and conidia, are given (where $\mathrm{n}>10)$ as: $(\min .-)\{\mathrm{X}-\mathrm{SD}\}_{-}\{\mathrm{X}+$ $\mathrm{SD}\}(-$ max.), where min and max are the extreme values, $\mathrm{X}$ the arithmetic mean and SD the corresponding standard deviation. Studied specimens are housed in the mycological herbarium of the V. L. Komarov Botanical Institute in St.-Petersburg (LE-Fungi).

\section{Collecting localities in Jammu and Kashmir State of India}

1: Tawi River, $33^{\circ} 11.784^{\prime} \mathrm{N}, 74^{\circ} 15.263^{\prime} \mathrm{E}$, alt. $600 \mathrm{~m}$, rocks by the river, 24 Apr 2013.

2: Bhaderwah, $33^{\circ} 06.252^{\prime} \mathrm{N}, 75^{\circ} 20.595^{\prime} \mathrm{E}$, alt. $1530 \mathrm{~m}$, garden, 25 Apr 2013.

3: Pahalgam, $34^{\circ} 00.567^{\prime} \mathrm{N}, 75^{\circ} 18.659^{\prime} \mathrm{E}$, alt. $2200 \mathrm{~m}$, coniferous forest, 27 Apr 2013.

4: vicinities of Tangmarg, $34^{\circ} 04.200^{\prime} \mathrm{N}, 74^{\circ} 49.488^{\prime} \mathrm{E}$, alt. $2160 \mathrm{~m}$, rocks in coniferous forest near a river, 29 Apr 2013.

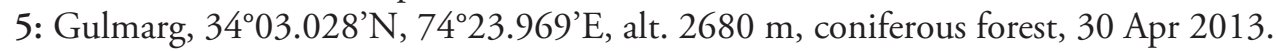

6: vicinities of Tangmarg, $34^{\circ} 04.200^{\prime} \mathrm{N}, 74^{\circ} 49.488^{\prime} \mathrm{E}$, alt. $2180 \mathrm{~m}$, coniferous forest near a river, 30 Apr 2013.

7: vicinities of Wullar Lake, $34^{\circ} 22.223^{\prime} \mathrm{N}, 7^{\circ} 31.299^{\prime} \mathrm{E}$, alt. $1830 \mathrm{~m}$, mixed forest, 1 May 2013.

8: Sonmarg, $34^{\circ} 22.224^{\prime} \mathrm{N}, 74^{\circ} 31.291^{\prime} \mathrm{E}$, alt. $2405 \mathrm{~m}$, open Ca-rocks among coniferous forest, 3 May 2013.

9: Lamayuru, $34^{\circ} 16.950^{\prime} \mathrm{N}, 76^{\circ} 46.337^{\prime} \mathrm{E}$, alt. $3390 \mathrm{~m}$, rocks in mountain desert, 5 May 2013.

10: near Khardung-La pass, $34^{\circ} 19.890^{\prime} \mathrm{N}, 77^{\circ} 38.810^{\prime} \mathrm{E}$, alt. $4650 \mathrm{~m}$, boulders in mountain desert, 9 May 2013.

11: vicinities of Leh, $34^{\circ} 14.908^{\prime} \mathrm{N}, 77^{\circ} 37.185^{\prime} \mathrm{E}$, alt. $4560 \mathrm{~m}$, boulders in mountain desert, 10 May 2013.

12: vicinities of Leh, $34^{\circ} 11^{\prime} 25.3^{\prime \prime} \mathrm{N}, 77^{\circ} 34^{\prime} 49.1^{\prime \prime} \mathrm{E}$, alt. $3880 \mathrm{~m}$, rocks in mountain desert, 12 May 2013. 


\section{List of species}

\section{Arthonia molendoi (Frauenf.) R. Sant.}

Causes slight discoloration of host tissues. Formerly known in Asia from Israel (Navrotskaya et al. 1996), Iran (Seaward et al. 2008), Turkey (Hafellner \& John 2006), Tajikistan (Kondratyuk \& Kudratov 2002) and Russia (Zhurbenko \& Hafellner 1999).

Specimen examined. 10: on Xanthoria elegans (apothecia, thallus), 9 May 2013, M. Zhurbenko 1381 (LE 260 547).

\section{Cercidospora macrospora (Uloth) Hafellner \& Nav.-Ros.}

Ascomata 125-200 $\mu \mathrm{m}$ diam., protruding only in ostiolar area to semi-immersed. Exciple in the upper half dark olive-brown outside, blue-green inside, ca $40 \mu \mathrm{m}$ thick, in the lower half pale olive-brown to almost colorless, ca $20 \mu \mathrm{m}$ thick. Asci cylindrical, 83-102 × 11-13 $\mu \mathrm{m},(2-) 4(-6)$-spored. Ascospores narrowly ellipsoid to narrowly obovoid or rarely almost fusiform, (18-)20.5-25.5(-31.5) $\times(5.5-) 6.5-7.5(-8) \mu \mathrm{m}, 1 / \mathrm{b}$ $=(2.5-) 3.0-3.8(-4.8)(\mathrm{n}=70),(0-) 1$-septate, not or slightly constricted at the septum, cells equal in shape and size or the upper one slightly wider, often with several conspicuous guttules, smooth-walled, non-halonate. Distinct pathogenicity not observed. Description of the species by Calatayud et al. (2013) prescribes just 1-septate and somewhat narrower ascospores 4-6(-7) $\mu \mathrm{m}$ wide, with cells equal in shape and size. However, their taxonomy was based only on herbarium specimens (P. Navarro-Rosinés, pers. comm.) and my measurements refer to the 'living' material, which usually has somewhat larger ascomatal structures (Baral 1992). Cercidospora macrospora is known from numerous collections from all over the northern hemisphere, including specimens from the Himalayas within Nepal and Pakistan (Calatayud et al. 2013).

Specimen examined. 11: on pale buff-yellow Lecanora species with small marginal lobes, growing on siliceous rock (equally frequent on thallus and discs and margins of apothecia), 10 May 2013, M. Zhurbenko 1334 (LE 261 098).

\section{Cercidospora melanophthalmae Nav.-Ros., Calat. \& Hafellner}

Ascomata 150-250 $\mu \mathrm{m}$ diam., mostly semi-immersed. Exciple blue-green and partly olive or brown above, pale brown to colorless below, K-. Asci (4-)8-spored. Ascospores narrowly obovate to occasionally ellipsoid, sometimes attenuated at one or both ends, $(14.5-) 19.5-25.5(-31) \times(4.5-) 6-7.5(-8.5) \mu \mathrm{m}, \mathrm{l} / \mathrm{b}=(2.7-) 3.0-3.8(-4.5)$ ( $\mathrm{n}=80$, in water or K), (0-)1-septate, not or rarely slightly constricted at the septum, with wider and usually slightly shorter upper cell, often with a few large guttules, smooth-walled, non-halonate. In the species protologue its ascospores are given somewhat smaller, viz. (16-)18-22(-24) × (4-)5-6.5(-7) (Calatayud et al. 2013), which can reflect differences between fresh and aged material (see pertinent note under Cercidospora macrospora). Formerly known in Asia from Syria, Armenia, Afghanistan and Pakistan (Calatayud et al. 2013).

Specimen examined. 10: on Rhizoplaca melanophthalma (discs and margins of apothecia, thallus), 9 May 2013, M. Zhurbenko 1359 (LE 260 918). 
Cercidospora xanthoriae (Wedd.) R. Sant.

Formerly known in Asia from Turkey (Hafellner \& John 2006) and Russia (Zhurbenko 2009b).

Specimen examined. 11: on Xanthoria elegans (thallus), 10 May 2013, M. Zhurbenko 1383 (LE 261 116).

\section{Cercidospora sp.}

Ascomata 125-150(-175) $\mu \mathrm{m}$ diam., immersed to slightly protruding in ostiolar area. Exciple dark olive throughout except blue-green inner rim above, 35-40 $\mu \mathrm{m}$ thick near ostiole, 15-20 $\mu \mathrm{m}$ thick below, K-. Asci cylindrical, (63-)70-82(-90) × (8-)9-11(-12) $\mu \mathrm{m}(\mathrm{n}=21$, in water, $\mathrm{K}$ or $\mathrm{K} / \mathrm{I}), 4(-8)$-spored. Ascospores narrowly ellipsoid to fusiform, with rather acute ends, (16.5-)24-32.5(-36.5) x (5.5-)5.5-6.5(-7.5) $\mu \mathrm{m}, 1 / \mathrm{b}=$ $(2.8-) 4.0-5.4(-6.4)(\mathrm{n}=38$, in water or $\mathrm{K} / \mathrm{I}),(0-) 1$-septate, not or slightly constricted at the septum, cells mostly equal in shape and size, sometimes slightly heteropolar, usually with several conspicuous lipid drops, smooth-walled, distinct halo not observed. Causes production of convex cecidia and slight bleaching of host thallus. Compared to the Cercidospora species growing on lichens of the genera Aspicilia, Lecanora, Lobothallia, Rhizoplaca and Squamarina (Navarro-Rosinés et al. 2004, 2009; Calatayud et al. 2013) examined material is most close to C. macrospora (growing on Lecanora saxicola group) and also resembles C. crozalsiana (H. Olivier) Nav.-Ros., Cl. Roux \& Casares (growing on Squamarina). Descriptions of the former species differ in presenting the exciple colorless or slightly green-blue in its lower half and the ascospores somewhat smaller, (19-)20-25(-30) $\times 4-6(-7) \mu \mathrm{m}$, and just 1-septate. Cercidospora crozalsiana differs in having larger ascomata, (160-)200-280 $\mu \mathrm{m}$, often colorless at the base exciple, (2-)4-spored and longer asci, 85-120 × 10-14 $\mu \mathrm{m}$, and mostly halonate ascospores.

Specimen examined. 10: on pale olive-yellow Lecanora species with small marginal lobes growing on siliceous rock (thallus), 9 May 2013, M. Zhurbenko 1336 (LE 261077 ).

\section{Cladosporium licheniphilum Heuchert \& U. Braun}

Xanthoria candelaria is a new host species. Formerly known in Asia from Russia on Pertusaria alpina (Heuchert \& Braun 2006).

Specimen examined. 7: on Xanthoria candelaria (soralia, thallus), 1 May 2013, M. Zhurbenko 1369 (LE 260 998).

Corticifraga peltigerae (Fuckel) D. Hawksw. \& R. Sant.

Causes strong discoloration of host tissues. Despite many previous records on various hosts, Peltigera elisabethae and P. ponojensis are likely to be new host species. It is noteworthy that Peltigera ponojensis, a lichen with circumpolar temperate to arctic distribution (Vitikainen 1994), is absent in the recent compendium of the macrolichens of India (Awasthi 2007). Formerly known in Asia from Russia (Zhurbenko 2009b).

Specimens examined. 6: on Peltigera elisabethae (thallus), 30 Apr 2013, M. Zhurbenko 1353 (LE 260 537). - 7: on P. ponojensis (thallus), 1 May 2013, M. Zhurbenko 1348 (LE $260997)$. 


\section{Endococcus incrassatus Etayo \& Breuss}

Ascomata semi-immersed, about $200 \mu \mathrm{m}$ diam. Ascospores ellipsoid, occasionally obovoid or oblong, ends usually rounded or sometimes rather acute, rarely with small papilla at one end, hyaline then medium brown, (11-)12.5-15(-17) × (6-)6.5-8(-9.5) $\mu \mathrm{m}, \mathrm{l} / \mathrm{b}=(1.4-) 1.6-2.2(-2.9)(\mathrm{n}=40$, in water or $\mathrm{I})$, simple or 1-septate with median septum and usually equal cells, not or rarely slightly constricted at the septum, usually with numerous small lipid drops, sometimes finely verruculose (DIC !), non-halonate. Pathogenicity not observed. Examined material supports suggestion that the species is conspecific with Endococcus karlstadtensis Kocourková \& Brackel (Zhurbenko et al. 2012a), described from Endocarpon pusillum. Endococcus incrassatus was formerly reported only from Placidiopsis cinerascens and from a sterile squamulose terricolous lichen. New to Asia.

Specimen examined. 1: on Endocarpon pusillum (thallus), 24 Apr 2013, M. Zhurbenko 1319 (LE 260 407).

\section{Endococcus rugulosus $\mathrm{Nyl}$. s. lat.}

Ascomata 100-200 $\mu \mathrm{m}$ diam. Ascospores ellipsoid or occasionally slightly obovoid, mostly with rounded ends, olive then brown, $(11.5-) 12-14.5(-16) \times 7.5-9.5(-13) \mu \mathrm{m}$, $\mathrm{l} / \mathrm{b}=(1.2-) 1.4-1.8(-2.0)(\mathrm{n}=25), 0-1$-septate, not or rarely slightly constricted at the septum, usually with numerous small lipid drops, smooth-walled. Formerly known in Asia from Iran (Seaward et al. 2008), Turkey (Halici et al. 2007b) and Russia (Zhurbenko 2009a).

Specimen examined. 6: on Aspicilia sp. growing on siliceous rock (thallus), $30 \mathrm{Apr}$ 2013, M. Zhurbenko 1362 (LE 261 218).

Intralichen christiansenii (D. Hawksw.) D. Hawksw. \& M.S. Cole

Formerly known in Asia from Israel (Temina et al. 2005), Iran (Seaward et al. 2008), Turkey (Hafellner \& John 2006), Russia (Zhurbenko \& Hafellner 1999) and China (Hawksworth \& Cole 2003).

Specimen examined. 10: on Candelariella aurella (disc of apothecia), 9 May 2013, M. Zhurbenko 1320 (LE 260 467).

Lichenoconium usneae (Anzi) D. Hawksw.

Infected host parts are discolored. Formerly known in Asia from Iran (Sohrabi \& Alstrup 2007), Turkey (Hafellner \& John 2006) and Russia (Zhurbenko 2009a).

Specimen examined. 3: on Flavoparmelia caperata (thallus), 27 Apr 2013, M. Zhurbenko 1344 (LE 260 928).

\section{Lichenoconium xanthoriae M.S. Christ.}

Infected host parts are discolored. Melanelixia is a new host genus. New to Asia.

Specimen examined. 6: on Melanelixia subargentifera (thallus), 30 Apr 2013, M. Zhurbenko 1343 (LE 261 228). 
Lichenodiplis lecanorae (Vouaux) Dyko \& D. Hawksw.

Formerly known in Asia from Turkey (Hafellner \& John 2006) and Russia (Zhurbenko et al. 2012b).

Specimens examined. 3: on Caloplaca cerina (discs of apothecia), 27 Apr 2013, M. Zhurbenko 1318 (LE 261 008); on Xanthoria candelaria (thallus), 27 Apr 2013, M. Zhurbenko 1371 (LE 261 087).

Lichenostigma alpinum (R. Sant., Alstrup \& D. Hawksw.) Ertz \& Diederich

Formerly known in Asia from Iran (Sohrabi \& Alstrup 2007), Turkey (Halici et al. 2007d), Russia (Zhurbenko 2009a) and China (Hawksworth \& Cole 2003).

Specimen examined. 6: on Pertusaria albescens (soralia, thallus), 30 Apr 2013, M. Zhurbenko 1339 (LE 261 328).

\section{Lichenostigma cosmopolites Hafellner \& Calat.}

The species strongly recalls a species of Sphaerellothecium. Formerly known in Asia from Turkey, Iran, Georgia, Nepal, China and Japan (Hafellner \& Calatayud 1999; Aptroot \& Sipman 2001; Hawksworth \& Cole 2003; Sohrabi \& Alstrup 2007).

Specimen examined. 7: on Xanthoparmelia stenophylla (thallus), 1 May 2013, M. Zhurbenko 1341 (LE 261 198).

\section{Lichenostigma cf. elongatum Nav.-Ros. \& Hafellner}

Vegetative hyphae forming black, superficial, not or scarcely ramified strands, $50-150(-300) \times(10-) 20-30(-50) \mu \mathrm{m}$, consisting of up to 8 rows of cells and grouped in black patches on the host surface. Ascomata irregularly globose to elongated, 150-250 $\mu \mathrm{m}$ lengthways. Ascospores hyaline then medium olive-brown and finally dark brown, obovoid, 1(-2)-septate, not or slightly constricted at the equatorial septum, verruculose, sometimes with halo up to $2.5 \mu \mathrm{m}$ wide, (11-)13-15(-16) $\times(6.5-) 7-8(-9.5) \mu \mathrm{m}$, $\mathrm{l} / \mathrm{b}=(1.5-) 1.8-2.0(-2.3) \quad(\mathrm{n}=38)$ [somewhat swollen in $\mathrm{K}:(10-) 13.5-17(-19.5)$ $\times(6.5-) 8-10(-11.5) \mu \mathrm{m}, 1 / \mathrm{b}=1.5-1.9(-2.1)(\mathrm{n}=42)]$. Occasionally causes slight discoloration of host tissues. According to Calatayud et al. (2002) ascospores of the species are just 1-septate and somewhat shorter, (9-)10-13 × 6-8.5 $\mu \mathrm{m}$, but later Calatayud et al. (2004) mentioned that its ascospores are occasionally 2-septate as well. Examined material is also similar to Lichenostigma rouxii Nav.-Ros., Calat. \& Hafellner growing on Squamarina species, which has 1(-3)-septate ascospores, (10-)10.5-13.5(-15.5) $\times(5.5-) 6-7(-8) \mu \mathrm{m}$ (Calatayud et al. 2004). However, vegetative hyphae of that species are scattered, never grouped in dense clusters, 400-1000 × 8-13 $\mu \mathrm{m}$, formed of (1-)2-3 rows of cells, and ascomata are till $120 \mu \mathrm{m}$ lengthways. Lichenostigma elongatum was formerly known in Asia from Iran (Valadbeigi \& Sipman 2010), Syria (John et al. 2004), Turkey (Hafellner \& John 2006) and Russia (Zhurbenko 2009b).

Specimens examined. 11: on pale grey Lecanora sp. with marginal lobes, growing on siliceous rock (thallus), 10 May 2013, M. Zhurbenko 1333 (LE 261 126). - 12: on Lobothallia praeradiosa (discs and margins of apothecia, thallus), 12 May 2013, M. Zhurbenko 1331 (LE 261 078). 
Lichenostigma subgen. Lichenogramma sp.

Fig. 1

The examined material possibly represents an undescribed species of Lichenostigma subgen. Lichenogramma Nav.-Ros. \& Hafellner (see key: Fernandez-Brime et al. 2010). Ascomata about $50 \mu \mathrm{m}$ lengthways, subglobose, associated with superficial, black, richly ramified, ornamented hyphal strands, $20-60(-100) \times 7-15(-20) \mu \mathrm{m}$, consisting of $1-3$ rows of cells. Ascospores hyaline then medium olive-brown and finally dark brown, broadly obovoid, (9-)10-12 $\times$ $6-7.5(-8.5) \mu \mathrm{m}, 1 / \mathrm{b}=(1.4-) 1.5-1.7(-1.8)(\mathrm{n}=25)$, 1-septate, markedly constricted at the septum, smooth-walled, when immature with halo 1-2 $\mu \mathrm{m}$ thick. Distinct pathogenicity not observed. Most Lichenostigma species are specific to a particular host genus, and none of them has so far been reported on Seirophora. The only Lichenostigma species known on lichens of the same host family Teloschistaceae is L. bolacinae Nav.-Ros., Calat. \& Hafellner (Calatayud et al. 2004). It grows on Caloplaca bolacina and can be distinguished by its ascospores, which are smaller, 8-9.5 × 5-6 $\mu \mathrm{m}$, slightly constricted at the septum, ornamented and non-halonate. It is noteworthy that the host lichen Seirophora contortuplicata, though widely distributed in the mountain regions of the northern hemisphere (Frödén et al. 2004), is absent in the recent compendium of the macrolichens of India (Awasthi 2007).

Specimen examined. 12: on Seirophora contortuplicata (apothecia, thallus), 12 May 2013, M. Zhurbenko 1366 (LE 261 117).
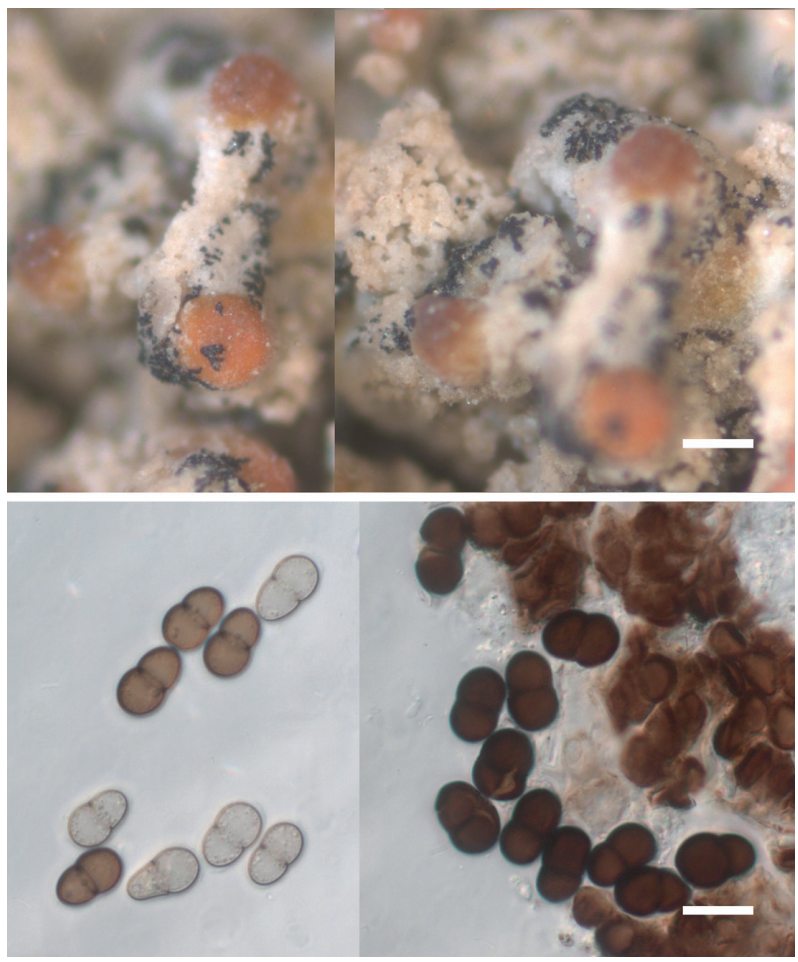

Fig. 1. Lichenostigma subgen. Lichenogramma sp. on Seirophora contortuplicata (LE 261117). Habitus (above, bar $=200 \mu \mathrm{m})$ and ascospores in water $($ below, bar $=10 \mu \mathrm{m})$ 
Marchandiomyces corallinus (Roberge) Diederich \& D. Hawksw.

Formerly known in Asia from Russia (Zhurbenko 2008) and China (Hawksworth \& Cole 2003).

Specimen examined. 7: on thalli of neighbouring Physcia aipolia and Xanthoria candelaria, 1 May 2013, M. Zhurbenko 1370 (LE 260 417).

\section{Monodictys epilepraria Kukwa \& Diederich}

New to Asia.

Specimen examined. 6: on Lepraria sp. growing on mosses (thallus), 30 Apr 2013, M. Zhurbenko 1314 (LE 261 288).

Muellerella erratica (A. Massal.) Hafellner \& V. John

Ascomata 150-250 $\mu \mathrm{m}$ diam. Ascospores (5.5-)6-8(-9.5) $\times(3-) 3.5-4(-5.5) \mu \mathrm{m}, \mathrm{l} / \mathrm{b}$ $=(1.2-) 1.6-2.2(-3.1)(\mathrm{n}=77)$. Formerly known in Asia from Iran (Seaward et al. 2008), Turkey (Hafellner \& John 2006), Russia (Zhurbenko 2009b), Pakistan (Poelt \& Grube 1993), China (Poelt \& Grube 1993) and Nepal (Triebel 1989).

Specimens examined. 10: on Lecidea lapicida (thallus), 9 May 2013, M. Zhurbenko 1315 (LE 260 958). - 11: on pale buff-yellow Lecanora sp. with tiny marginal lobes, growing on siliceous rock (thallus), 10 May 2013, M. Zhurbenko 1325 (LE 261 108).

Muellerella pygmaea (Körb.) D. Hawksw.

Ascomata 150-250 $\mu \mathrm{m}$ diam. Ascospores (6.5-)7.5-10(-13.5) $\times(4-) 5-6(-7.5) \mu \mathrm{m}$, $\mathrm{l} / \mathrm{b}=(1.3-) 1.4-2.0(-3.4)(\mathrm{n}=93)$. Infected host parts are sometimes slightly discolored. The species was formerly known in Asia from Iran (Seaward et al. 2008), Turkey (Hafellner \& John 2006), Tajikistan (Kondratyuk \& Kudratov 2002), Russia (Triebel 1989, Zhurbenko 2009b) and China (Hawksworth \& Cole 2003).

Specimens examined. 9: on Xanthoria elegans (thallus), 5 May 2013, M. Zhurbenko 1376 (LE 260 487). - 11: on X. elegans (thallus, occasionally apothecia), 10 May 2013, M. Zhurbenko 1372 (LE 260 517); M. Zhurbenko 1373 (LE 260 447); M. Zhurbenko 1374 (LE 260427). - 12: on brown Acarospora sp. growing on siliceous rock (thallus), 12 May 2013, M. Zhurbenko 1317 (LE 261 177).

Nectriopsis lecanodes (Ces.) Diederich \& Schroers

Peltigera elisabethae and P. scabrosa are new host species. It is noteworthy that Peltigera scabrosa, a lichen with circumpolar boreal to arctic distribution (Vitikainen 1994), is absent in the recent compendium of the macrolichens of India (Awasthi 2007). Formerly known in Asia from Russia (Zhurbenko \& Davydov 2000).

Specimens examined (all on moribund parts of Peltigera spp. thalli). 6: on $P$. elisabethae, 30 Apr 2013, M. Zhurbenko 1351 (LE 261 209); on P. scabrosa, 30 Apr 2013, M. Zhurbenko 1349 (LE 261 348). - 7: on P. cf. scabrosa, 1 May 2013, M. Zhurbenko 1347 (LE 261057 ). 


\section{Phoma sp.}

Conidia $(4.5-) 5.5-6.5(-8) \times 3.5-4(-4.5) \mu \mathrm{m}, \mathrm{l} / \mathrm{b}=(1.1-) 1.2-1.8(-2.1)(\mathrm{n}=21)$. Infected host tissues become darker.

Specimen examined. 5: on Xanthoria elegans (apothecia), 30 Apr 2013, M. Zhurbenko 1378 (LE 261 037).

Polycoccum clauzadei Nav.-Ros. \& Cl. Roux

Ascospores (14.5-)16.5-19.5(-22) × (6.5-)7-8(-8.5) $\mu \mathrm{m}, 1 / \mathrm{b}=(2.1-) 2.2-2.6(-2.9)$ $(\mathrm{n}=29)$. Formerly known in Asia from an uncertain report from Russia (Urbanavichene $\&$ Urbanavichus 2007).

Specimen examined. 11: on Xanthoria elegans (apothecia, thallus), 10 May 2013, M. Zhurbenko 1380 (LE 261 007).

Polycoccum pulvinatum (Eitner) R. Sant.

Ascospores olive then brown, more or less ellipsoid, 1-septate, not or slightly constricted at the septum, verrucose, sometimes with halo up to $3 \mu \mathrm{m}$ thick, diagonally uniseriate in an ascus, slightly shorter than reported by Hawksworth (1975), viz. $(13.5-) 14.5-16.5(-17) \times 7.5-8.5(-9.5) \mu \mathrm{m}, 1 / \mathrm{b}=(1.5-) 1.7-2.1(-2.2)(\mathrm{n}=26)$ vs. $14-18(-21) \times 7-9 \mu \mathrm{m}$. Formerly known in Asia from Iran (Sohrabi \& Alstrup 2007) and Russia (Zhurbenko 2009b).

Specimen examined. 6: on Physcia dubia (thallus), 30 Apr 2013, M. Zhurbenko 1356 (LE 261 298).

\section{Pronectria subimperspicua (Speg.) Lowen}

Ascospores are slightly longer than reported for the species type by Rossman et al. (1999), namely (5.5-)7-9(-10.5) × (4-)4.5-5.5(-6) $\mu \mathrm{m}, \mathrm{l} / \mathrm{b}=(1.1-) 1.3-1.9(-2.2)(\mathrm{n}=$ $35)$ vs. 6.5-8 $\times 5-6 \mu \mathrm{m}$. Associated with discolored areas on the host thallus. Formerly known in Asia from China (Santesson 1998).

Specimen examined. 2: on Punctelia borreri (thallus), 25 Apr 2013, M. Zhurbenko 1346 (LE 261 168).

Pyrenidium actinellum $\mathrm{Nyl}$. s. lat.

Ascomata associated with necrotic patches or dark swellings on the host thallus. Formerly known in Asia from Turkey (Halici et al. 2007c), Russia (Zhurbenko 2009b) and China (Hafellner \& Obermayer 1995).

Specimens examined. 6: on Peltigera elisabethae (thallus), 30 Apr 2013, M. Zhurbenko 1350 (LE 261 208); on P. praetextata (thallus), 30 Apr 2013, M. Zhurbenko 1352 (LE $261458)$.

Rosellinula frustulosae (Vouaux) R. Sant.

Pathogenicity not observed. Formerly known in Asia from Iran (Sohrabi \& Alstrup 2007), Turkey (Halici et al. 2007a), Kyrgyzstan (Nadyeina \& Halici 2011) and Mongolia (Hafellner 1985). 
Specimen examined. 12: on Lecanora argopholis (thallus), 12 May 2013, M. Zhurbenko 1328 (LE 261017 ).

\section{Sarcogyne sphaerospora J. Steiner}

Ascospores ellipsoid to globose, $(3-) 4-5(-6) \times(3-) 3.5-4(-4.5) \mu \mathrm{m}, 1 / \mathrm{b}=1.0-1.4(-2.0)$ $(n=63)$. Lichenization was not observed, which matches with observations of K. Knudsen (pers. comm.). This rarely reported species seems to be so far known in Asia only from the type locality in eastern Turkey (Steiner 1899) and from Tajikistan (Kudratov \& Mayrhofer 2002).

Specimens examined (both on thalli of Candelariella species or occasionally on siliceous rock nearby them). 10: 9 May 2013, M. Zhurbenko 1322 (LE 261 106). - 11: 10 May 2013, M. Zhurbenko 1323 (LE 260 996).

Sphaeropezia cf. lecanorae (Diederich \& Marson) Baloch \& Wedin

Ascomata $350-500 \mu \mathrm{m}$ diam., pore 30-150 $\mu \mathrm{m}$ diam., margin radially fissured. Ascospores ellipsoid to narrowly ellipsoid, 3-septate, (10.5-)12-14.5(-16) $\times$ $(4.5-) 5-6.5(-7.5) \mu \mathrm{m}, \mathrm{l} / \mathrm{b}=(1.8-) 2.1-2.7(-2.8)(\mathrm{n}=22$, in water or $\mathrm{K} / \mathrm{I})$, wall $\mathrm{K} / \mathrm{I}+$ pale blue. Sphaeropezia lecanorae is the only species of the genus known from saxicolous placidioid Lecanora species of the L. muralis group. However, in the species protologue its ascospores were reported as being smaller, viz. (9-)10-11.5(-13) $\times(3.5-) 4-5(-6.5)$ $\mu \mathrm{m}$ (Diederich et al. 2002). Examined material also fits description of "Odontotrema sp. 3 ", characterized by ascospores of similar size, (12-)13-15.5(-17) $\times(4.5-) 5-6 \mu \mathrm{m}$, but growing on corticolous and lignicolous, non-placidioid Lecanora symmicta and L. pulicaris (Diederich et al. 2002). Both species are as yet known only from a few collections and the variability of their ascomatal characters is insufficiently known. Sphaeropezia lecanorae has hitherto not been reported from Asia.

Specimen examined. 6: on Lecanora muralis s. lat. (thallus), 30 Apr 2013, M. Zhurbenko 1332 (LE 261 418).

Stigmidium gyrophorarum (Arnold) D. Hawksw.

Causes local darkening of the host thallus. Formerly known in Asia from Turkey (Halici et al. 2007e), Tajikistan (Kondratyuk \& Kudratov 2002) and Russia (Zhurbenko \& Santesson 1996).

Specimen examined. 4: on Umbilicaria vellea (thallus), 29 Apr 2013, M. Zhurbenko 1365 (LE 261 338).

Stigmidium pumilum (Lettau) Matzer \& Hafellner

Ascomata 30-70 $\mu \mathrm{m}$ diam., mostly semi-immersed, associated with poorly visible dark hyphae. Asci (26-)26.5-34(-39) × (11-)11.5-15.5(-16.5) $(\mathrm{n}=11)$, wall BCr-. Ascospores narrowly obovoid with wider upper cell, hyaline, smooth-walled, 1-septate, when over-mature occasionally pale brown, verruculose and/or 2-septate, markedly constricted at the septum, $(11-) 12.5-14.5(-15.5) \times 4-4.5 \mu \mathrm{m}, 1 / \mathrm{b}=(2.8-) 2.9-3.5(-3.7)$ $(\mathrm{n}=37)$, usually with 1-2 large lipid drops in each cell, non-halonate, wall BCr-. 
Infection associated with darkened areas on the host lobes. Formerly known in Asia from Iran (Sohrabi \& Alstrup 2007), Turkey (Hafellner \& John 2006) and Russia (Zhurbenko 2009b).

Specimen examined. 6: on Phaeophyscia ciliata (thallus), 30 Apr 2013, M. Zhurbenko 1342 (LE 261258 ).

Stigmidium tabacinae (Arnold) Triebel

Ascomata 50-70 $\mu \mathrm{m}$ diam., semi-immersed, associated with immersed brown hyphae. Ascospores hyaline, narrowly obovoid, (7.5-)8-10(-11) $\times(3-) 3.5-4 \mu \mathrm{m}, 1 / \mathrm{b}=$ $(2.1-) 2.2-2.6(-2.8)(\mathrm{n}=19$, in water or BCr), 1-septate, slightly constricted at the septum, smooth-walled, usually with several conspicuous lipid drops (sometimes pseudotetrablastic), non-halonate. Walls of asci and ascospores BCr-. Triebel (1989) reported for the species somewhat longer ascospores, (10-)11.5-12.5(-14) $\times(3-) 3.5-4 \mu \mathrm{m}$. Formerly known in Asia from Iran (Sohrabi \& Alstrup 2007), Turkey (Hafellner \& John 2006) and Russia (Zhurbenko 2009a).

Specimen examined. 8: on Toninia tristis (thallus), 3 May 2013, M. Zhurbenko 1363 (LE 260 988).

Vouauxiella lichenicola (Linds.) Petr. \& Syd.

Distinct pathogenicity not observed. Formerly known in Asia from Turkey (Etayo \& Breuss 1998).

Specimens examined [both on Lecanora spp. from L. subfusca group (discs of apothecia)]. 3: 27 Apr 2013, M. Zhurbenko 1327 (LE 261 107). - 5: 30 Apr 2013, M. Zhurbenko 1329 (LE 261 027).

Zwackhiomyces coepulonus (Norman) Grube \& R. Sant.

Ascospores (18-)20-25.5(-27) × (5.5-)6-7 $\mu \mathrm{m}, 1 / \mathrm{b}=(2.7-) 3.1-3.9(-4.0)(\mathrm{n}=17)$, which corresponds to the measurements of Zhurbenko (2009b) [(15-)18.5-23(-25) $\times$ (5.5-)6-7(-8) $\mu \mathrm{m}, 1 / \mathrm{b}=(2.1-) 2.6-3.6(-4.4)]$, but differs from those of Grube \& Hafellner $(1990)[(15-) 16-20(-21) \times 5.5-8.5(-9) \mu \mathrm{m}, 1 / \mathrm{b}=2.6]$. Sometimes associated with slightly discolored portions of the host lobes. Formerly known in Asia from Israel (Navrotskaya et al. 1996), Turkey (Hafellner \& John 2006), Russia (Zhurbenko 2009b) and Mongolia (Huneck et al. 1992).

Specimen examined. 11: on Xanthoria elegans (apothecia, thallus), 10 May 2013, M. Zhurbenko 1375 (LE 260 437).

Zwackhiomyces cf. kiszkianus D. Hawksw. \& Miądl.

Fig. 2

Ascomata black, more or less pyriform, 150-250 $\mu \mathrm{m}$ diam., protruding only in ostiolar area to semi-immersed, scattered. Exciple about 30-40 $\mu$ m thick, brown throughout, $\mathrm{K}_{+}$ olive. Ostiolar filaments 30-35 × 2.5-3.5 $\mu \mathrm{m}$. Interascal filaments abundant, hyaline, branched, anastomosed, 2-3.5 $\mu \mathrm{m}$ diam. Asci subcylindrical to narrowly clavate, usually with distinct foot and with ocular chamber ca $2 \mu \mathrm{m}$ tall, (89-)93-113(-120) $\times(14-) 15-19(-20)$ $\mu \mathrm{m}(\mathrm{n}=16$, in water or $\mathrm{K} / \mathrm{I})$, originally 8 -spored, but sometimes with $2-4$ mature spores. 


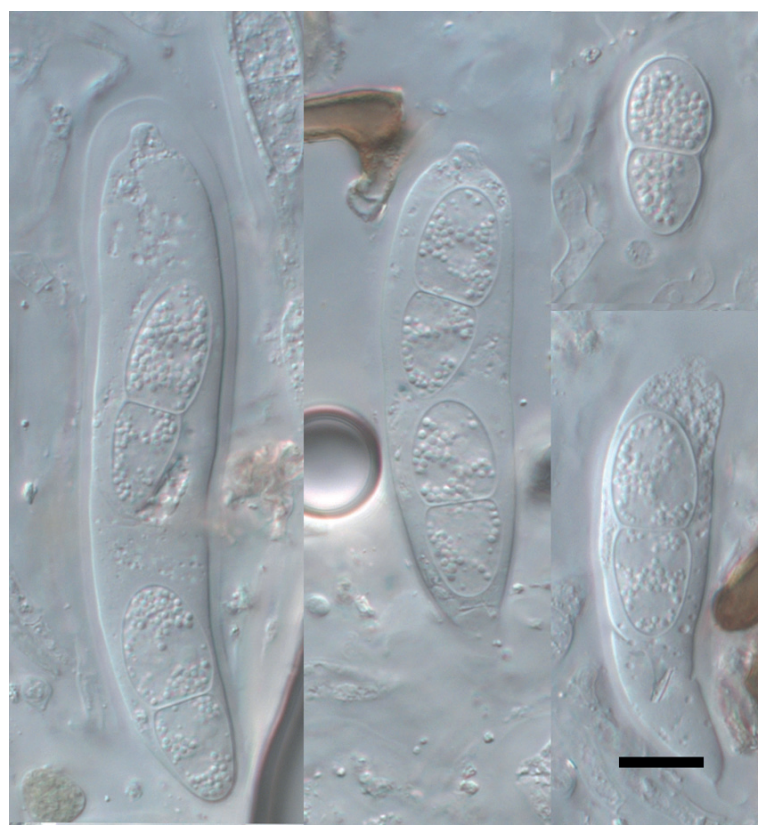

Fig. 2. Zwackhiomyces cf. kiszkianus on Peltigera elisabethae (LE 260507). Asci and ascospores in water. Bar $=10 \mu$

Ascospores narrowly obovoid, 1-septate, usually markedly constricted at the septum, with wider and often somewhat longer upper cell, (19-)23.5-29(-33) $\times(7-) 8.5-11(-12.5) \mu \mathrm{m}$, $1 / b=(1.8-) 2.4-3.0(-3.2)(n=60$, in water or $K)$, with numerous small lipid drops, smoothwalled, non-halonate, refractive spots not observed. Sometimes causes local discoloration of the host tissues. There are some differences between the examined material and the species protologue (Hawksworth \& Miądlikowska 1997), where its ascomata were said to be immersed and not associated with any necrotic patches, interascal filaments $1-2 \mu \mathrm{m}$ diam., asci $90-105 \times 14-15.5 \mu \mathrm{m}$, ascospores shorter $(19.5-25.5 \times 8.5-13 \mu \mathrm{m})$, with a refractive spot at the junction of wall and septum, surrounded by a perispore with a granular internal ornamentation. However, the species was previously known only from the type collection in Germany (on Peltigera canina), and it is possible that its ascomatal characters have a wider range of variation.

Specimen examined. 4: on Peltigera elisabethae (upper, occasionally lower sides of lobes), 29 Apr 2013, M. Zhurbenko 1354 (LE 260 507).

\section{Discussion}

The list includes 36 species of lichenicolous fungi, all of which except Endococcus rugulosus are new to India, thus increasing the number of these fungi species known from the country to 42 . Taking into consideration that: 1) Awasthi (2007) enumerated 874 species 
of macrolichens from India, Nepal and Sri Lanka, which should be less than half of the total lichen species number of the area; 2) in the well-studied regions of the Holarctic ratio of the number of lichen species to the number of lichenicolous fungi species is roughly equal to 5:1 (Zhurbenko 2007); 3) the British Isles, with far fewer potential host lichens and a much smaller geographical area, has at least 460 species of lichenicolous fungi (B.J. Coppins, pers. comm.), it is likely that the true richness of lichenicolous fungi in India is far in excess of 400 species.

Acknowledgements. Uwe Braun, Paul Diederich, Kerry Knudsen and Pere Navarro-Rosinés are thanked for the help in identification of Cladosporium licheniphilum, Lichenodiplis lecanorae, Sarcogyne sphaerospora and Cercidospora species respectively. I am grateful to Boris Gannibal, Alexander Andreev and Vladimir Skvortsov for the good company during trip to Jammu and Kashmir.

\section{References}

Alstrup, V. \& Ahti, T. 2007. New reports of lichenicolous fungi, mainly from Finland and Russia. Karstenia 47: 1-4.

Aptroot, A. \& Sipman, H.J.M. 2001. New Hong Kong lichens, ascomycetes and lichenicolous fungi. Journal of the Hattori Botanical Laboratory 91: 317-343.

Awasthi, D.D. 2007. A compendium of the macrolichens from India, Nepal and Sri Lanka. Bishen Singh Mahendra Pal Singh, Dehra-Dun, India.

Baral, H.-O. 1992. Vital versus herbarium taxonomy: morphological differences between living and dead cells of ascomycetes, and their taxonomic implications. - Mycotaxon 44: 333-390.

Calatayud, V., Navarro-Rosinés, P. \& Hafellner, J. 2002. A synopsis of Lichenostigma subgen. Lichenogramma (Arthoniales), with a key to the species. - Mycological Research 106: 1230-1242. doi: 10.1017/ S095375620200655X

Calatayud, V., Hafellner, J. \& Navarro-Rosinés, P. 2004. Lichenostigma. - In: T.H. Nash III, B.D. Ryan, P. Diederich, C. Gried \& F. Bungartz (eds). Lichea flora of the Greater Sonoran Desert Region. Vol. 2. Pp. 664-669. Lichens Unlimited, Arizona State University, Tempe, Arizona.

Calatayud, V., Navarro-Rosinés, P. \& Hafellner, J. 2013. Contributions to a revision of Cercidospora (Dothideales), 2: Species on Lecanora s. 1., Rhizoplaca and Squamarina. - Mycosphere 4: 539-557.

Coppins, B.J. \& Kondratyuk, S.Y. 1998. Opegrapha trassii sp. nov., a new lichenicolous fungus on Heterodermia. - Folia Cryptogamica Estonica 32: 9-14.

Diederich, P., Zhurbenko, M. \& Etayo, J. 2002. The lichenicolous species of Odontotrema (syn. Lethariicola) (Ascomycota, Ostropales). - Lichenologist 34: 479-501. doi: 10.1006/lich.2002.0418

Etayo, J. \& Breuss, O. 1998. New species and interesting records of lichenicolous fungi. - Österreichische Zeitschrift für Pilzkunde 7: 203-213.

Fernandez-Brime, S., Llimona, X. \& Navarro-Rosinés, P. 2010. Lichenostigma rupicolae (Lichenotheliaceae), a new lichenicolous species growing on Pertusaria rupicola. - Lichenologist 42: 241-247. doi: 10.1017/ S0024282909990727 
Frödén, P., Ryan, B.D. \& Kärnefelt, I. 2004. Teloschistes. - In: T.H. Nash III, B.D. Ryan, P. Diederich, C. Gried \& F. Bungartz (eds). Lichea flora of the Greater Sonoran Desert Region. Vol. 2. Pp. 524-529. Lichens Unlimited, Arizona State University, Tempe, Arizona.

Grube, M. \& Hafellner, J. 1990. Studien an flechtenbewohnenden Pilzen der Sammelgattung Didymella (Ascomycetes, Dothideales). - Nova Hedwigia 51(3-4): 283-360.

Hafellner, J. 1985. Studien über lichenicole Pilze und Flechten III. Die Gattung Roselliniella Vainio emend. Haf. (Ascomycotina, Dothideales). - Herzogia 7: 145-162.

Hafellner, J. \& Calatayud, V. 1999. Lichenostigma cosmopolites, a common lichenicolous fungus on Xanthoparmelia species. - Mycotaxon 72: 107-114.

Hafellner, J. \& John, V. 2006. Über Funde lichenicoler nicht-lichenisierter Pilze in der Türkei, mit einer Synopsis der bisher im Land nachgewiesenen Taxa. - Herzogia 19: 155-176.

Hafellner, J. \& Obermayer, W. 1995. Cercidospora trypetheliza und einige weitere lichenicole Ascomyceten auf Arthrorhaphis. - Cryptogamie, Bryologie-Lichénologie 16: 177-190.

Halici, M., Aksoy, A. \& Kocakaya, M. 2007a. Some lichens from Gaziantep, Kahramanmaraş, Kırşehir and Yozgat provinces (Turkey). - Turkish Journal of Botany 31: 161-170.

Halici, M.G., Candan, M. \& Turk, A.O. 2007b. New records of lichenicolous and lichenized fungi from Turkey. - Mycotaxon 100: 255-260.

Halici, M.G., Hawksworth, D.L. \& Aksoy, A. 2007c. Contributions to the lichenized and lichenicolous fungal biota of Turkey. - Mycotaxon 102: 403-414.

Halici, M., Hawksworth, D.L. \& Aksoy, A. 2007d. New and interesting lichenicolous fungi records from Turkey. - Nova Hedwigia 85(3-4): 393-401.

Halici, M.G., Turk, A.O. \& Candan, M. 2007e. New records of pyrenocarpous lichenicolous fungi from Turkey. - Mycotaxon 99: 201-206.

Hariharan, G.N., Mibey, R.K. \& Hawksworth, D.L. 1996. A new species of Lichenopeltella on Porina in India. - Lichenologist 28: 294-296. doi: 10.1017/S0024282996000370

Hawksworth, D.L. 1975. Notes on British lichenicolous fungi, I. - Kew Bulletin 30: 183-203. doi: $10.2307 / 4102884$

Hawksworth, D.L. \& Cole, M.S. 2003. A first checklist of lichenicolous fungi from China. - Mycosystema 22: 359-363.

Hawksworth, D.L. \& Miądlikowska, J. 1997. New species of lichenicolous fungi occurring on Peltigera in Ecuador and Europe. - Mycological Research 101: 1127-1134. doi: 10.1017/ S0953756297003778

Heuchert, B. \& Braun, U. 2006. On some dematiaceous lichenicolous hyphomycetes. - Herzogia 19: 11-21.

Huneck, S., Ahti, T., Cogt, U., Poelt, J. \& Sipman, H. 1992. Zur Verbreitung und Chemie von Flechten der Mongolei. III. Ergebnisse der Mongolisch-Deutschen Biologischen Expedition seit 1962 Nr. 217. - Nova Hedwigia 54(3-4): 277-308.

John, V., Seaward, M.R.D., Sipman, H.J.M. \& Zedda, L. 2004. Lichens and lichenicolous fungi of Syria, including a first checklist. - Herzogia 17: 157-177.

Kondratyuk, S.Y. \& Kudratov, I. 2002. New for Tajikistan lichenicolous and lichen-forming fungi. Ukrainian Botananical Journal 2): 165-170.

Kudratov, I. \& Mayrhofer, H. 2002. Catalogue of the lichenized and lichenicolous fungi of Tajikistan. Herzogia 15: 91-128. 
Moreau, F. 1951. Un champignon lichenicole cecidogene, Phyllosticta galligena, sp. nov. - Bulletin de la Société Botanique de France 98(4-6): 100-102.

Nadyeina, O. \& Halici, M.G. 2011. New lichenicolous fungi records for Kyrgyzstan, Uzbekistan, and Ukraine. - Mycotaxon 118: 131-136. doi: 10.5248/118.131

Navarro-Rosinés, P., Calatayud, V. \& Hafellner, J. 2004. Cercidospora. - In: T.H. Nash III, B.D. Ryan, P. Diederich, C. Gried \& F. Bungartz (eds). Lichea flora of the Greater Sonoran Desert Region. Vol. 2. Pp. 635-639. Lichens Unlimited, Arizona State University, Tempe, Arizona.

Navarro-Rosinés, P., Calatayud, V. \& Hafellner, J. 2009. Contributions to a revision of the genus Cercidospora (Dothideales) 1. Species on Megasporaceae. - Mycotaxon 110: 5-25. doi: 10.5248/110.5

Navrotskaya, I.L., Kondratyuk, S.Y., Wasser, S.P., Nevo, E. \& Zelenko, S.D. 1996. Lichens and lichenicolous fungi new for Israel and other countries. - Israel Journal of Plant Sciences 44: 181-196. doi: 10.1080/07929978.1996.10676646

Poelt, J. \& Grube, M. 1993. Beiträge zur Kenntnis der Flechtenflora des Himalaya VIII-- Lecanora subgen. Placodium. - Nova Hedwigia 57(3-4): 305-352.

Rossman, A.Y., Samuels, G.J., Rogerson, C.T. \& Lowen, R. 1999. Genera of Bionectriaceae, Hypocreaceae and Nectriaceae (Hypocreales, Ascomycetes). - Studies in Mycology 42: 1-248.

Santesson, R. 1998. Fungi lichenicoli exsiccati. Fasc. 11 \& 12 (nos. 251-300). - Thunbergia 28: 1-19.

Seaward, M.R.D., Sipman, H.J.M. \& Sohrabi, M. 2008. A revised checklist of lichenized, lichenicolous and allied fungi for Iran. - Sauteria 15: 459-520.

Sherwood, M.A., Hawksworth, D.L. \& Coppins, B.J. 1981. Skyttea, a new genus of odontotremoid lichenicolous fungi. - Transactions of the British Mycological Society 75[1980]: 479-490. doi: 10.1016/S0007-1536(80)80130-6

Sohrabi, M. \& Alstrup, V. 2007. Additions to the lichen mycota of Iran from East Azerbaijan Province. - Mycotaxon 100: 145-148.

Steiner, J. 1899. Flechten aus Armenien und dem Kaukasus. - Oesterreichische Botanische Zeitschrift 49: 248-254, 292-295.

Temina, M., Kondratyuk, S., Zelenko, S.D., Nevo, E. \& Wasser, S. 2005. Lichen-forming, lichenicolous, and allied fungi of Israel. A.R. Gantner Verlag K.-G., Ruggell, Liechtenstein.

Triebel, D. 1989. Lecideicole Ascomyceten. Eine Revision der obligat lichenicolen Ascomyceten auf lecideoiden Flechten. - Bibliotheca Lichenologica 35: 1-278.

Urbanavichene, I.N. \& Urbanavichus, G.P. 2007. [To the lichen flora of Oka Plateau (Eastern Sayan, Republic of Buryatia)]. - Novitates Systematicae Plantarum non Vascularium [St.-Petersburg] 43: 229-245. (In Russian)

Valadbeigi, T. \& Sipman, H.J.M. 2010. New records of lichens and lichenicolous fungi from Iran and their biogeographical significance. - Mycotaxon 113: 191-194. doi: 10.5248/113.191

Vitikainen, O. 1994. Taxonomic revision of Peltigera (lichenized Ascomycotina) in Europe. - Acta Botanica Fennica 152: 1-96.

Zhurbenko, M.P. 2007. [Lichenicolous fungi of Russia: history and first synthesis of exploration]. Mikologiya i Fitopatologiya 41: 481-486. (In Russian)

Zhurbenko, M.P. 2008. Lichenicolous fungi from Russia, mainly from its Arctic. II. - Mycologia Balcanica 5: 13-22.

Zhurbenko, M.P. 2009a. Lichenicolous fungi and some lichens from the Holarctic. - Opuscula Philolichenum 6: 87-120. 
Zhurbenko, M.P. 2009b. Lichenicolous fungi and lichens from the Holarctic. Part II. - Opuscula Philolichenum 7: 121-186.

Zhurbenko, M.P. \& Davydov, E.A. 2000. Lichenicolous fungi and some lichens from the Russian Altai, southern Siberia. - Folia Cryptogamica Estonica 37: 109-118.

Zhurbenko, M.P. \& Hafellner, J. 1999. Lichenicolous fungi from the Putorana plateau, Siberian Subarctic. - Folia Cryptogamica Estonica 34: 71-79.

Zhurbenko, M.P. \& Santesson, R. 1996. Lichenicolous fungi from the Russian Arctic. - Herzogia 12: 147-161.

Zhurbenko, M.P., Hermansson, J. \& Pystina, T.N. 2012a. Endococcus incrassatus new to Eurasia and some other lichenicolous fungi from the Komi Republic of Russia. - Graphis Scripta 24: 36-39.

Zhurbenko, M.P., Himelbrant, D.E., Kuznetsova, E.S. \& Stepanchikova, I.S. 2012b. Lichenicolous fungi from the Kamchatka Peninsula, Russia. - Bryologist 115: 295-312. doi 10.1639/0007-2745115.2.295 